\title{
Engaging Young Audiences Before, During and After the Lockdown
}

\author{
Anna Catalani, Heather Hughes
}

\begin{abstract}
This short article focuses on two heritage sites (the International Bomber Command Centre and Creswell Crags) and reflects on the ways in which such medium-size institutions are trying to find ways of maintaining offsite engagement with young audiences while at the same time generating revenues.
\end{abstract}

\section{Introduction}

Before the pandemic-induced emptiness of British public places, museums and heritage centres were working hard to expand and diversify audiences. Under-12s often constitute a significant visitor group through school and family visits (Briggs 2007; Cicero and Teichert 2018). The over-12 segment of 'Generation Z' tends to be perceived as difficult to reach; research has therefore focused on why they are absent from museums (Mason and McCarthy 2006; Gofman et al. 2011; Hughes and Moscardo 2019) and how to engage their interest (Manna and Palumbo 2018; Schuch et al. 2018; Batat 2020).

Notwithstanding the digital shift of the past decades, both scholarly research and audience development have assumed that the aim of reaching out to the young is to encourage them to visit physical sites. Online gaming and immersive experiences are considered useful, as long as they do not detract from this aim. According to Haddad (2016: 61), 'there are still not enough [virtual applications in the field of heritage edutainment] to make the required and hoped-for change for the children of the digital natives generation'.

With physical sites inaccessible and little time to prepare, how have heritage sites reached out to youthful audiences, and what have they learned about rebuilding activities to engage them? In this paper we explore these questions through two cases in the East Midlands, which we had been researching prior to the pandemic. Creswell Crags lies on the Nottinghamshire-Derbyshire border and the International Bomber Command Centre (IBCC) is located on a hill overlooking Lincoln. Both are independent, medium sized heritage sites, governed by charitable trusts. Both furloughed all but a handful of employees, which constrained their ability to offer online activities and plan for the future.

\section{The IBCC}

The IBCC is a memorial to those killed while serving in RAF Bomber Command during the Second World War. Its visitor centre houses an exhibition telling the story of the bombing war in Europe, mostly relying on digital interactives but including a small number of original artefacts.

It appeals primarily to an older demographic, although it has done much to engage younger audiences, mostly in the 5-12 age range, through school visits and an informal learning programme. This includes family fun days and 'crafternoon' activities. School children also attend the Remembrance service in large numbers (700 in November 2019).

The first online activity the IBCC organized post lockdown was 'Operation Gratitude', a call-out via social media to send letters, poems or pictures to veterans, to help them overcome isolation. There were over 800 responses, overwhelmingly from young people; feedback from veterans called it 'brilliant'. ' The campaign happened because of the lockdown; an unintended 
consequence was that the IBCC extended its reach well beyond the East Midlands.

The IBCC's Learning Officer also compiled downloadable activities for children and started blogposts with ideas for craft projects. ${ }^{2}$ The Centre hosts several Duke of Edinburgh's Award ${ }^{3}$ volunteers; they contributed to the blogposts, thus promoting new forms of interaction between teens and under-12s. One of these - a recipe for potato scones - proved very popular. ${ }^{4}$ These resources have been shared with organizations such as Visit Lincoln and Lincoln Mums. In addition, the IBCC's YouTube channel was refreshed as a medium for digital storytelling. An extensive digital archive is attached to the IBCC, hosted and managed by the University of Lincoln. In response to the lockdown, archive staff, together with Italian research NGO Lapsus, produced a bilingual online resource for secondary school learners and Italian museum outreach activities. ${ }^{5}$

\section{Creswell Crags}

Creswell Crags provides a different example. A scheduled ancient monument, its limestone caves contain the only known ice age art in Britain; many cave artefacts are displayed in its accredited museum. Prior to the lockdown, it was a popular destination for organized school visits, while family visits and events like birthday parties were also mainstays. The majority of volunteers were students from local specialist colleges. How to engage these youthful audiences without a physical site was therefore a 'steep learning curve'. 6

An early step was to share existing pre- and post-visit educational resources more widely for home learning. By fortunate coincidence, the site's first poet in residence, PhD student Hannah Cooper-Smithson, had just begun her six-month stint in January 2020. She devised activities suitable for all youth age groups, including poetry workshops and a poetry competition for under and over $16 \mathrm{~s}^{7}$

While the lockdown hit the IBCC hard, Creswell Crags faced the prospect of permanent closure due to loss of revenue. In consequence, online activity has focused heavily on a fundraising campaign. The justgiving.com platform, with its easy-to-use interface, was chosen because staff felt it was familiar to young people; they have indeed supported the campaign enthusiastically. ${ }^{8}$ Social media, especially Pinterest and Instagram (again, because of its youthful support base), have also been employed to raise the site's profile. Significantly, through these channels during the lockdown, staff have identified more clearly what appeals to young audiences: not so much the ice age as the witch marks that cover the walls of one of the caves, the biggest such collection in Britain.

\section{The future?}

In addition to other assistance, both sites received emergency support from the National Lottery Heritage Fund, enabling them to cover the costs of re-opening and to develop new offers. It is unlikely that school visits will resume before the spring of 2021; numbers of visitors to the sites, as well as secondary spending, are anticipated to be much reduced. A considerable challenge they have identified, therefore, is to maintain offsite engagement while generating income from it.

Both sites are planning to charge for outreach activities, which may well be attractive to schools as cost effective, less time-consuming and with potential to reach a wider spectrum of pupils than traditional field trips. The IBCC is planning mobile exhibitions, activity kits and loan boxes to be sent to schools in advance of virtual, real-time sessions. Since aviation heritage is central to Lincolnshire's identity, IBCC will extend its outreach to cover this local history element of the primary curriculum. It also plans to link schools in different countries to key events (for example, the Netherlands and Operation Manna). Onsite, family fun days and 'crafternoons' will resume with social distancing and safety measures in place.

Creswell Crags is developing a virtual cave for use on or offsite. It will feature close-up encounters with the witch marks, and ice age artefacts will be presented in their context. As part of a tailor-made schools programme, this will enable remote income generation. It will also enhance experiences onsite, as real caves are not accessible to everyone. In addition, new onsite offers, such as premium family cave tours, are planned. 


\section{Conclusion}

Despite the time constraints and lack of staff, both sites have been responsive to youthful audiences and have devised novel ways to interact with them. Through this short paper we have argued that the two sites, while still aiming predominantly at under-12s, have nevertheless demonstrated a greater sensitivity to the needs of teen audiences. Their experiences suggest that knowledge gained through the lockdown could well contribute to that much-needed digital leap identified by Haddad. That is surely an important ambition for heritage institutions wishing to win the support of youthful audiences in the UK and elsewhere - whether they possess unique artefacts, such as Creswell Crags, or like the IBCC, do not.

Received: 29 June 2020

Finally accepted: 17 August 2020

\section{Notes}

1 Nicky Van Der Drift, Chief Executive, IBCC, interview via Zoom by Heather Hughes, 2 June 2020.

2 See https://internationalbcc.co.uk/your-visit-events/for-families/, accessed 29 June 2020, and https://internationalbcc.co.uk/about-ibcc/news/category/kids/, accessed 29 June 2020; Jess Van Der Drift, Learning Officer, IBCC, interview via Zoom by Heather Hughes, 2 June 2020.

3 A youth awards programme encouraging self-improvement, initiated by the Duke of Edinburgh in the 1950s.

4 See https://internationalbcc.co.uk/about-ibcc/news/potato-scones/, accessed 17 August 2020.

5 See https://ibccdigitalarchive.lincoln.ac.uk/omeka/why-do-they-bomb-us, accessed 29 June 2020.

6 Rebecca Morris-Buck, Communications Officer, Creswell Crags, interview via Zoom by Heather Hughes, 26 June 2020.

7 See https://www.creswell-crags.org.uk/2020/06/10/creswell-crags-poetry-competitionresults/, accessed 29 June 2020.

8 See https://www.justgiving.com/creswell-crags, accessed 29 June 2020.

\section{References}

Batat, W. (2020) 'How Can Art Museums Develop New Business Opportunities? Exploring Young Visitors' Experience', Young Consumers, 21(1) 109-31.

Briggs, S. (2007) 'Fresh Eyes: Attracting and Sustaining Young Visitors to Tate', Museum Management and Curatorship, 22 (1) 5-9.

Cicero, L. and Teichert, T. (2018) 'Children's Influence in Museum Visits: Antecedents and Consequences', Museum Management and Curatorship, 33 (2) 146-57.

Gofman, A., Moskowitz, H.R. and Mets, T. (2011) 'Marketing Museums and Exhibitions: What Drives the Interest of Young People', Journal of Hospitality Marketing \& Management, 20 (6) 601-18.

Haddad, N.A. (2016) 'Multimedia and Cultural Heritage', Virtual Archaeology Review, 7 (14) 61-73. 
Hughes, K. and Moscardo, G. (2019) 'For Me or Not For Me? Exploring Young Adults' Museum Representations', Leisure Sciences, 41 (6) 516-34.

Manna, R. and Palumbo, R. (2018) 'What Makes a Museum Attractive to Young People? Evidence from Italy', International Journal of Tourism Research, 20 508-17.

Mason, D.D.M. and McCarthy, C. (2006) “'The Feeling of Exclusion”: Young Peoples' Perceptions of Art Galleries', Museum Management and Curatorship, 21 (1) 20-31.

Schuch, J.C., Harden, S.B., Bostick, K. and Smith, H.A. (2018) 'Museums Engaging Diverse Millennials Community Dialogue', Museums \& Social Issues, 13 (2) 58-77.

\section{Authors}

\section{Anna Catalani}

School of Design

University of Lincoln

United Kingdom

acatalani@lincoln.ac.uk

\section{Heather Hughes}

Professor of Cultural Heritage Studies, Lincoln International Business School, University of Lincoln LN6 7TS

United Kingdom

hhughes@lincoln.ac.uk 